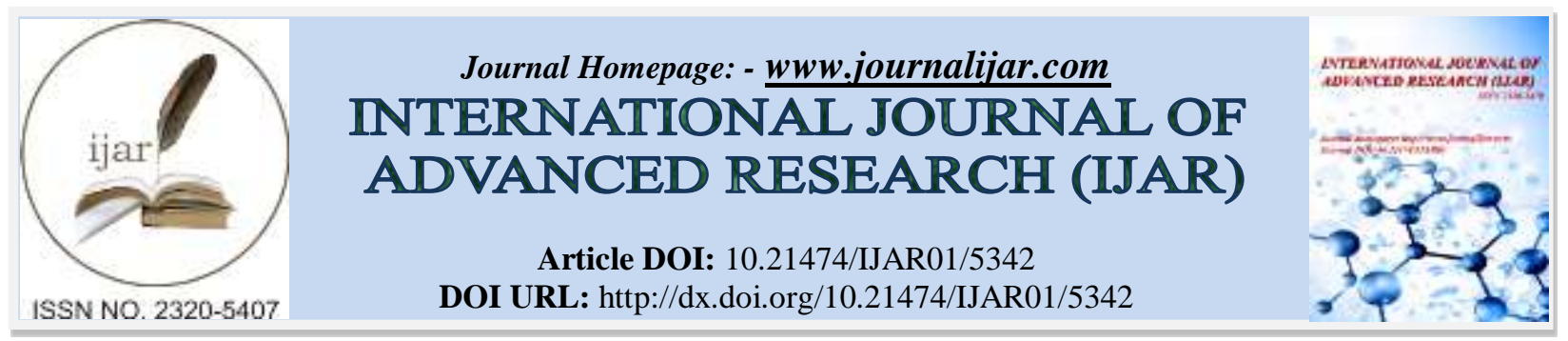

RESEARCH ARTICLE

\title{
CLINICAL EVALUATION OF ASTHISAMHARADI CHURNA WITH ASHWAGANDHA IN THE MANAGEMENT OF ASTHI BHAGNA (FRACTURE).
}

Dr. Manish Kumar Alok.

Reader, Department of Shalya Tantra, Saint Sahara Ayurvedic Medical College, Bhatinda.

\section{Manuscript Info}

Manuscript History

Received: 05 July 2017

Final Accepted: 07 August 2017

Published: September 2017

Key words:-

Asthi Bhagna, Fracture, Sandhi Bhagna.

\section{Abstract}

Bhagna (Fracture) is an epitome where bone or bones get interrupted. Everyday 40 to 50 percent cases of opd are suffering from such type of ailments. Few traditional practitioners specifically dealing with fractures called 'BONE SETTERS' have been effectively using herbo-mineral drugs over many centuries. The drug (ASTHISAMRADHI CHURNA WITH ASHWAGANDHA) studied has shown to reduce the various complications encountered after the removal of plaster of Paris (pop). Asthisamharadi churna with Ashwagandha, has also effective role in reducing the total duration of treatment.

Copy Right, IJAR, 2017,. All rights reserved.

\section{Introduction:-}

Bhagna is an epitome where bone or bones get interrupted. This is classified on the basis of its clinical importance in to Avrana (Simple fracture) and Savrana (Compound fracture).In modern literature, a fracture is defined as a break or loss of continuity in the substance of the bone. Acharya Sushruta has advocated the principles of reducing the fracture. They are Anchana (Traction), Peedana (Manipulation), Sankeshpana (Opposition), and Bandhana (Immobilization) which is practiced regularly even today. In modern orthopedics the simple fractures are managed by closed reduction followed by application of POP.

Few traditional practitioners specifically dealing with fractures have been effectively using herbo-mineral drugs over many centuries. Many of these drugs are simple, easily available, cost effective and potent. The scientific evaluation of such drugs along with their fundamental principles is essential for their universal acceptance. Hence in this study an attempt is made to prepare a drug about which there are textural references regarding Asthibhagna sandhan, through clinical trial in the present study it has been tried to prove the efficacy of the Ashthisamharadi churna with Ashwagandha in asthibhangna.

Asthisamharadi churna contain asthisamhara, laksha, godhuma and arjuna with anupana ghee and ksheera. In addition to these four contents Ashwagandha was added in it because according to textual references Ashwagandha has quality such as rasayana, balya, vrana hara, sopha nashaka, kshata hara and vatakapha nashaka.

\section{Aim \& Objectives:-}

Aim of the study was to evaluate the efficacy of the Ashthisamharadi churna with Ashwagandha in the management of asthibhangna (Fracture).

Corresponding Author: Dr. Manish Kumar Alok. 


\section{Material and Methods:-}

For the same purpose considering the classical description of the different Ayurvedic and modern literature, a research Proforma was prepared. The clinical evaluation of asthisamharadi churna and Ashwagandha in management of Asthi bhagna was assessed by the clinical study in 30 patients who were grouped in to two groups i.e. Group A, Managed by modern management.with Asthisamharadi churna and Ashwagandha, Group B, managed by modern management.

\section{Inclusion Criteria:-}

1. Simple or Closed Fractures.

2. Fractures of Humerus, Radius, Ulna, Tibia, Fibula, which can be reduced by closed reduction method with or without general anesthesia.

3. Stable fractures i.e. fractures in which the alignment of bony ends can be maintained without internal fixation.

\section{Exclusion Criteria:-}

1. Open or compound fractures.

2. Simple fractures with wounds were excluded.

3. Pathological fractures, Stress Fractures, and complicated fractures.

4. Fractures requiring open reduction and internal fixation.

5. Fractures associated with other debilitating diseases like Diabetes, Tuberculosis, Leprosy, Asthma is excluded.

6. Patients suggestive of Osteomyelitis and other bone diseases.

7. Patients above the age of 60 years and below the age of 10 years.

\section{Investigations:-}

\section{X- RAY:-}

$\mathrm{X}^{\prime}$ ray films were taken on ' $\mathbf{0}$ ' day to diagnose the fracture, its type, severity and prognosis. The follow up $\mathrm{X}^{\prime}$ ray films were taken at first week, fourth week after that weekly or biweekly till the clinical healing of fractured bone to assess the callus formation.

\section{Blood:-}

Hb, TC, DC, ESR, Blood sugar, Serum calcium

\section{Causes of Drug Selection:-}

1. The presence of constituent (in above drug-combination) which promote healing according to textual references.

2. Easy availability of the drug constituents and cost effective.

3. Simplicity in the drug preparation.

Constituents of Asthisamharadi Churna with Ashwagandha.

\begin{tabular}{|l|l|}
\hline Asthisamhara & Cissus quadrangularis Linn. \\
\hline Laksha & Laccifer lacca Kerr. \\
\hline Godhuma & Triticum aestivum Linn. \\
\hline Arjuna & Terminalia arjuna(Roxb.) w.\&A. \\
\hline Ashwagandha & Withania somnifera(Linn.)Dunal \\
\hline
\end{tabular}

\section{Management of Fracture in Group-A:-}

1. Initially the fractured bones were reduced by conventional closed reduction methods wherever necessary.

2. After reduction immobilization was achieved by conventional immobilization methods viz. Posterior slab of plaster of Paris, POP cast ball bandage etc.) Posterior slab was replaced by POP cast after 5 to 7 days when swelling at fracture site was reduced.

3. After clinical bony union the active physiotherapy was advised to the patients.

\section{Drug Supply and Dosage:-}

Asthisamharadi churna and Ashawaganda churna-3 gm,thrice a day with milk and ghee started on day "o"soon after reduction. 


\begin{abstract}
Ahara:-
Patient's usual vegetarian and non-vegetarian diet was continued with restrictions of Lavana, Katu, Amla rasa prachura, Kshara and Ruksha dravyas.

Vihara:-

Atyadhika maithuna, Atapa sevana and vyayama were restricted.

Management of Fractures in Group-B:-

It was managed in the same way as that of group-A patients but trial drug does not given to the patients of group-B.
\end{abstract}

\title{
Follow up:-
}

The total duration of the treatment was untill the clinical union of the fractured bone in each patient. Each patient was examined on initial day, i.e. Day '0' and further followed up at one week, fouth week and after that weekly. The changes in the baseline signs and symptoms of patients were recorded on each visit on the research Performa.

\section{Parameters of Assessment:-}

To assess the efficacy of the trial preparation or improvement in the clinical symptoms of the disease, different signs and symptoms were arbitrarily graded on the basis of severity. The changes in the gradation of each symptom were mentioned in the research Proforma. The clinical gradations of symptoms were as follows:

1. Pain: No pain-0

a. Tolerable pain -01

2. Swelling:

b. Intolerable pain -02

No swelling -00

a. At site-01

b. At related joint-02

c. At whole limb-03

3. Tenderness:

No tenderness-00

a. Patient winces-01

b. Patient winces and withdraws affected part-02

c. Patient does not allows to touch the part-03

4. loss of function:

Normal function-00

a. Able to perform with difficulty-01

b. Unable to perform : 2

5. Callus assessment: $\quad$ Good callus - 00

Mild callus -01

No callus -02

\section{Observation and Result:-}

As the aim of clinical study was to assess the efficacy of Asthisamharadi churna with Ashwagandha in fracture healing,pain \& swelling are important symptoms of fracture. The initial mean value of pain in group A was 1.8, and then it was reduced to 0.33 . In most of the patient after one week of observation it came down drastically. Hence these observations indicate the Asthisamharadi churna with ashwagandha has got analgesic action.

The observations towards swelling also show that there was drastic reduction of swelling after administration of drug. The initial mean value was 1.66 which was reduced to 0.26 after the drug administration. The same indicates the efficacy of drug in reducing the swelling. That means this drug has got definite role to play with antiinflammatory action.

As callus formation is the part of fracture healing, it is influenced by the patient, tissue, and treatment variables. Subsequently, these factors can influence the time of appearance of callus in the radiograph. The callus formation was early in those patients who were given Asthisamharadi churna with Ashwagandha. 
The graph shows the effect of therapy in group A

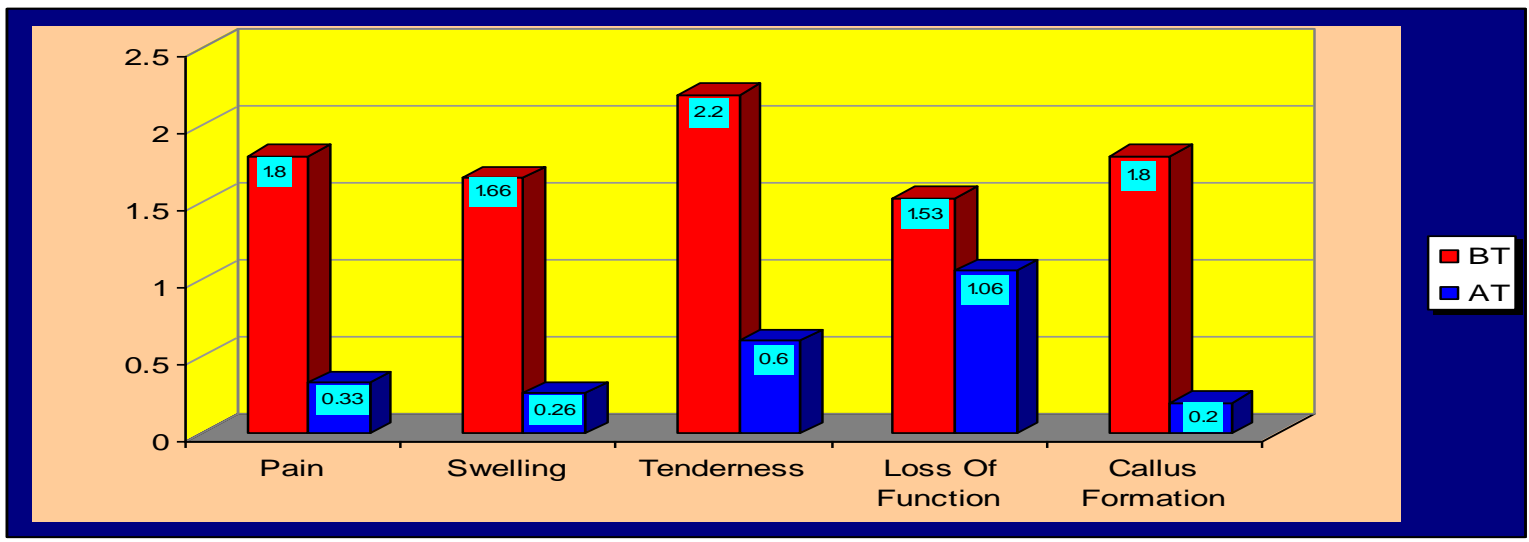

The graph shows the effect of therapy in group B

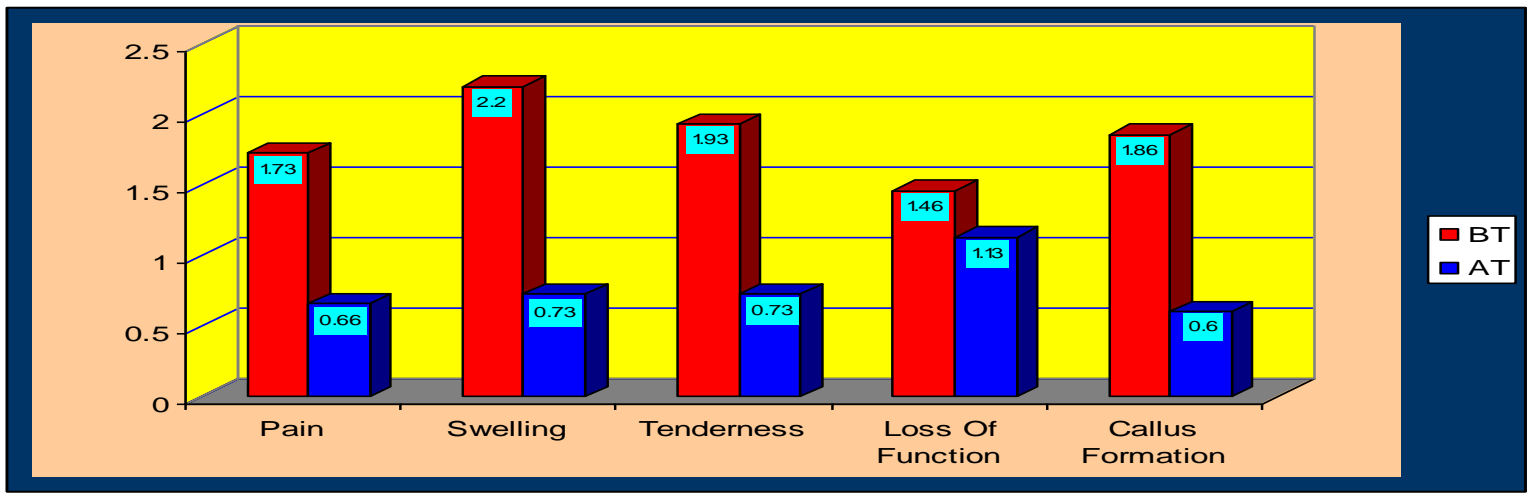

\section{Conclusion:-}

The essence of present work is derived out of study of 30 patients divided in two groups. Group A managed with reduction, immobilisation achieved with pop, (.i.e modern technique) and oral formulation of Asthisamharadi churna with Aashwagandha was given Group B managed same as group A but our formulation was not given. Each consisting of 15 patients with specific observation is presented here. Most of the cases were reported due to fall, vehicle accident, violence i.e. chief cause of fracture was trauma.

Pain and swelling are the two important and troublesome symptoms of fracture which needs an immediate clinical attention. From our study, it is clear that the drug has a beneficial effect in reducing symptoms and bone healing. To say authoritatively Ashtisamharadi churna with Ashwagandha had any added advantages, further studies should be carried out separately with the help of bio-chemical analysis. Administration of the drug is effective in reducing the total duration of treatment.

\section{References:-}

1. Agnivesh, In K R Srikantha Murthy Charak Samhita (text book with english translation) Vol I \& II, reprint edition, Varanasi, Chaukhambha Orientalia 2009.

2. Sushruta, In Sharma PV. Sushruta Samhita (with English translation of text and Dalhan's commentary along with critical notes) Vol I \& II, Reprint edition, Varanasi, Chaukhambha Visvabharti 2005.

3. Vagbhata, Ashtanga Hridayam, In K R Shrikantha Murthy, Ashtanga Sangraha of (text book with english translation) Vol I \& II, Third edition, Varanasi.

4. 'Yoga Ratnakara' with 'Vidyotini' Hindi commentary By Vd. Sri. Laksmipati Shastri, Ayurvedacharya. Edited by Bhisagratna Sri. Bhramashankar Shastri. Published by Choukhamba Sanskrit Sansthana, Varanasi.

5. 'Bhaishajya Ratnavali' with the Vidyotini Hindi commentary by Kaviraj Sri. Ambikadatta Shastri, Ayurvedacharya. Edited by Kaviraj Rajeshwardatt Shastri Ayurvedacharya. Published by Chaukambha Sanskrit Sansthana, Varnasi. 9th Edition 1991. 
6. Madhavakara, Madhava Nidanam, In Vijayarakshita and Srikantha Datta, Madhukosha (Sanskrit Commentary) and Vidyotini (Hindi Commentary along with critical notes) on Madhava Nidanam, Vol I \& II, reprint edition, Varanasi, Chaukhambha Sanskrit Sansthan, 2005.

7. 'Dravya Guna Vignyana' By Dr. Vishnu Mahadev Gogate. Published by continental publishers, Pune. 1st edition 1982.

8. Indian Medicinal Plants.II edition by Lt. Colonel. B D Basu. Edited, revised enlarged and mostly rewritten by E.Blatter, J F Caius and K S Bhaskar. Published by Lalit Mohan Basu, Vol. I, II, III and IV.

9. Indian Material Medical By Dr. K M Nadkarni, Originally edited by the Lt. Dr. K M Nadkarni, Revised and enlarged by A K Nadkarni, Forwarded by Colonel Sir. R N Chopra, Popular Prakashan Pvt. Ltd. Printed by A J Printers, Published by Ramdas G Bhatkal.

10. Methods in Bio-statistics for medical students and research workers. By Mr. B K Mahajan, Published by Jitendra P Vij, Jaypee brothers, Medical publishers (Pvt.) ltd. 5th edition 1989, reprint 1991

11. Fracture and Joint Injuries By Wattson - Jones. Edited by J N Wilson, B I Churchill, Livingstone.

12. Outline of fractures including joint injuries, By John Crawford Adams and David Hamblen, Published by Churchill Livingston, New-York. 11th edition 1999.

13. Handbook of Osteology By S Potdar and Ajay bhagat. Published by Scientific book company, Patna. 8th edition 1989.

14. Human Physiology By C.C. Chatterjee B.Sc., M.D (Cal), Volume I, 10th edition - July 1985, Special reprint 1991.

15. Clinical Methods in Surgery, By K. Das. 7th edition 1965. Calcutta. 